\title{
Improving the Quality of Anaerobically-Pretreated Palm Oil Mill Effluent Using Electrocoagulation
}

\author{
Illah Sailah ${ }^{1 *}$, Fathan Reyhanto', Tyara Puspaningrum', Muhammad Romli', \\ Suprihatin Suprihatin ${ }^{1}$, Nastiti Siswi Indrasti ${ }^{1}$ \\ 1 Department of Agroindustrial Technology, IPB University, Bogor, Indonesia \\ * Corresponding author's e-mail: illahsailah@apps.ipb.ac.id
}

\begin{abstract}
The palm oil extraction process generates large amounts of effluents with very high concentrations of pollutants, even though they are subjected to anaerobic pretreatment. Further treatment is needed in order to ensure that the effluent is safe for disposal or reuse. This work was conducted to evaluate the performance of an electrocoagulation process in removing pollutants from the anaerobically-pretreated palm oil mill effluent. A $1000 \mathrm{ml}$ beaker glass equipped with a magnetic stirrer was used as an electrocoagulation reactor with four plates of aluminum electrode @ $12 \times 2 \mathrm{~cm}$ and an effective area of $0.1 \mathrm{~m}^{2}$ arranged in a bipolar configuration. The experiments run in a batch mode were carried out at various voltage levels and contact times, namely 10,15 , and $20 \mathrm{~V}$ for 15,30 , 45 and $60 \mathrm{~min}$. The level of pollutant removal and electrical energy consumption were determined. The electrocoagulation process at $15 \mathrm{~V}$ for 30 min produced the highest level of pollutant removal for TSS, turbidity, color, $\mathrm{COD}$, and $\mathrm{BOD}_{5}$, i.e. $90 \%, 86 \%, 93 \%, 87 \%$, and $97 \%$, respectively. The estimated operating costs for these process conditions are $1.48 \mathrm{USD} / \mathrm{m}^{3}$. A second order empirical model was developed to describe the TSS removal in the POME electrocoagulation process. The electrocoagulation with aluminum electrodes can significantly reduce various types of pollutants of anaerobically-pretreated POME, such as TSS, turbidity, color, COD, and $\mathrm{BOD}_{5}$. The estimated cost of EC operation is cheaper than the chemical coagulation process.
\end{abstract}

Keywords: aluminum electrodes; electrocoagulation; empirical model; Palm oil mill effluent (POME); pollutant removals

\section{INTRODUCTION}

Palm oil (Elaeis guinensis Jacq.) is one of the most important commodities in the Indonesian economy. Indonesia's crude palm oil (CPO) production is growing at $11.5 \%$ per year. In 2020 , the $\mathrm{CPO}$ production is estimated at 49 million tons and palm kernel oil (PKO) at 10 million tons, making Indonesia the highest $\mathrm{CPO}$ producer in the world (BPS, 2019). The palm oil industry generates various wastes including oil palm trunks (OPT), mesocarp fibres (MF), empty fruit bunches (EFB), palm fronds, palm pressed fibres (PPF), oil palm kernel shells (OPKS), and palm oil mill effluent (POME) (Liew et al., 2018). The palm oil extraction process generates large amounts of effluents with very high concentrations of pollutants.
The process generates POME 3-4 $\mathrm{m}^{3} /$ ton CPO with COD 44,000-100,000 mg/L, BOD 25,000-66,000 mg/L, TSS 18,000-46,000 mg/L, and $\mathrm{pH}$ 3.4-5.2 (Wang et al., 2015). POME is a polluted industrial wastewater that may cause harm to the environment if discharged directly due to its biological oxygen demand (BOD) and chemical oxygen demand (COD) (Hossain et al., 2019). POME treatment is generally carried out in anaerobic open ponds. Although simple, inexpensive, low in energy, the systems have shortcomings in terms of long retention time, which is 116-192 days (Rahardjo, 2016), large space, and causing methane emissions. Some mills have implemented a methane capture system. Hasanudin et al. (2015) reported that this methane capture system is capable of producing renewable energy 
around $25-41 \mathrm{kWh} /$ ton fresh fruit bunch (FFB) and reducing the GHG emissions by $109-175 \mathrm{~kg}$ $\mathrm{CO}_{2} \mathrm{e} /$ ton FFB. However, the treated effluent still contains high concentrations of pollutants, i.e. $\mathrm{pH}$ of 7.5-7.8, color 4,190 PtCo, COD 1,400 mg/L, $\mathrm{BOD}_{5} 800 \mathrm{mg} / \mathrm{L}$, and turbidity of $650 \mathrm{NTU}$ (Sidik et al., 2019). These characteristics do not meet the effluent quality standards of the palm oil mill and therefore require further treatment. There are various treatments for managing POME in the palm oil industry. The coagulation method, by means of synthetic chemicals, has been frequently used for managing the effluents generated by a large number of industries. In this method, the colloidal particles are destabilized with chemical coagulants and separated from the liquid phase. However, synthetic or chemical coagulants have such disadvantages as the large amount of sludge produced and the remaining aluminium in treated water that caused the environmental impact (de Souza et al., 2014). Electrocoagulation (EC) has been developed as an alternative which is more environmentally-friendly. In EC, coagulants are formed through electro-dissolution of the anode, commonly aluminium or iron, which causes the destabilization of the pollutants by hydrolysis (Verma and Kumar 2018). Recent studies have shown that electrocoagulation (EC) is an effective alternative to purifying various types of wastewater. This method has various advantages, such as short processing time, occupying less space, no need for chemicals, simple equipment requirement and ease to operation (Butler et al., 2011; Rachmawati et al., 2014; Bharath et al., 2018). In this process metal anodes initiate the electrochemical reactions that provide active metal cations for coagulation, flocculation, and other physical-chemical processes that can eliminate various pollutants. This process has been proven successful in clarifying sugarcane juice (Noersatyo et al., 2020), treating dairy wastewater (Markou et al., 2017), purifying detergent wastewater (Suprihatin and Aselfa, 2020), decolorizing wastewater (Ibrahim et al., 2018); eliminating heavy metals $\mathrm{Cu}, \mathrm{Cr}$, and $\mathrm{Zn}$ (Singh and Mishra, 2016), and conducting defluoridation of drinking water (Essadki et al., 2010). The EC process is considered as a feasible and environmentally-friendly, as well as a cost-effective technology, with short startup period, simple operation, no addition of chemicals, high removal capabilities, easy collection of the produced sludge, and easy control (Al-Qodah et al., 2020). EC is a combination of the electrochemical and coagulation processes (Kabdaşl et al., 2012). The process includes oxidation and reduction which can reduce the stability of suspended, colloids, dissolved pollutants, and emulsion breakdown. As a result of the electric current in the electrode cells which are connected to an external power source, the anode oxidation dissolves the electrodes to produce positive metal ions which function as coagulants together with the production of hydroxyl ions and hydrogen gas at the cathode, thereby triggering the formation of floc which easily settles or floats by the hydrogen gas formed. The mechanism for removing various types of pollutants from wastewater has been described and discussed in various publications (Mollah et al., 2010; Marriaga-Cabrales and Machuca-Martínez, 2014; Brahmi et al., 2019). The removal efficiency and electrical energy consumption depends on many factors, including current density, temperature, time, concentration, $\mathrm{pH}$, and materials of electrodes (Islam, 2017; de la Luz-Pedro et al., 2019). The aims of this study were to evaluate the performance of the EC process in further removing the pollutants contained in anaerobically-pretreated POME and to calculate the energy consumption and operating cost of the electrocoagulation method. The empirical models were also developed to describe the EC process for treating the anaerobically-pretreated POME. This study was carried out in Bogor, Indonesia, in 2020.

\section{MATERIALS AND METHODS}

\section{Materials and EC reactor}

The anaerobically-pretreated POME used in this study was obtained from a CPO processing plant in West Java in January 2020. Visually the effluent was brownish black and very turbid with the characteristics as presented in Table 1.

Table 1. Characteristics of anaerobically-pretreated POME used in this study

\begin{tabular}{|c|c|c|}
\hline Parameter & Unit & Value \\
\hline $\mathrm{pH}$ & - & 8.17 \\
\hline TSS & $\mathrm{mg} / \mathrm{L}$ & $785 \pm 20$ \\
\hline Turbidity & NTU & $457 \pm 6$ \\
\hline Color & PtCo & $10,400 \pm 70$ \\
\hline $\mathrm{COD}$ & $\mathrm{mg} / \mathrm{L}$ & $6,000 \pm 100$ \\
\hline $\mathrm{BOD}_{5}$ & $\mathrm{mg} / \mathrm{L}$ & 2,740 \\
\hline
\end{tabular}


A $1000 \mathrm{~mL}$ beaker glass equipped with a magnetic stirrer was used as an electrocoagulation reactor. Four plates of $12 \times 2 \mathrm{~cm}$ aluminum electrode with an effective area of $0.1 \mathrm{~m}^{2}$ were arranged in a bipolar configuration with the distance between the electrodes of $1 \mathrm{~cm}$. Figure 1 shows the experimental set up that consists of the electrocoagulation reactor, a power supply, and a voltmeter.

\section{Experimental method}

All experiments were run in a batch mode. During the electrocoagulation process, the effluent was stirred using a magnetic stirrer at $100 \mathrm{rpm}$ at an initial temperature of $33^{\circ} \mathrm{C}$. Two independent variables were examined, namely the electric voltage and the contact time. Three levels of electric voltage, namely 10,15 , and $20 \mathrm{~V}$ and three levels of contact time, namely 30, 45 and $60 \mathrm{~min}$ were examined. Each experiment was carried out with two replications. After the electrocoagulation process was complete, stirring was stopped and the liquid was left for 1 hour to allow the floc to settle. Afterwards, the samples were taken from the supernatant to measure $\mathrm{pH}$, TSS, turbidity, color, $\mathrm{COD}$, and $\mathrm{BOD}_{5}$. The analysis of the effluent characteristics was carried out by referring to standard procedures, namely TSS, turbidity, color, $\mathrm{COD}, \mathrm{BOD}_{5}$, and $\mathrm{pH}$ (APHA, 2017).

\section{Data analysis}

The experimental data were analyzed statistically and the results were expressed in terms of pollutant removal, using Eq. (1). absolute removal $(\mathrm{Ct}-\mathrm{Co})$ or in percentage of

$$
\mathrm{R}(\%)=\frac{\left(\mathrm{C}_{0}-\mathrm{C}_{\mathrm{t}}\right)}{\mathrm{C}_{0}} 100
$$

where: $\mathrm{C}_{0}$ and $\mathrm{C}_{\mathrm{t}}$ are the pollutant concentrations at time 0 and $t$, and $\mathrm{R}$ is the pollutant removal.

On the basis of the experimental results, an empirical model was developed to describe the pollutant removal characteristics which is useful for designing the EC process. In addition, the operational costs estimation of the EC process was also conducted by calculating the electricity and the electrode consumption.

\section{RESULTS AND DISCUSSION}

\section{Pollutant removal TSS removal and turbidity}

The effect of electric voltage and contact time on the reduction of TSS is presented in Figure 2. The EC process drastically decreases TSS in the first $30 \mathrm{~min}$, followed by a slight decrease up to $45 \mathrm{~min}$, but there is no significant decrease afterward. The figure also shows that the removal rate of TSS increases along with electric voltage. Under $10 \mathrm{~V}$ operating conditions for $30 \mathrm{~min}$ there is a reduction in TSS by $76 \%$, whereas at $20 \mathrm{~V}$ for 60 min the reduction of TSS can reach $99 \%$ with a final effluent TSS of $11 \mathrm{mg} / \mathrm{L}$. The higher the voltage, the greater the electric current produced and the more $\mathrm{Al}^{3+}$ ions are formed. As a result, more flocks are formed and more suspended solids can be removed.

Turbidity of wastewater is closely related to organic and inorganic suspended materials and
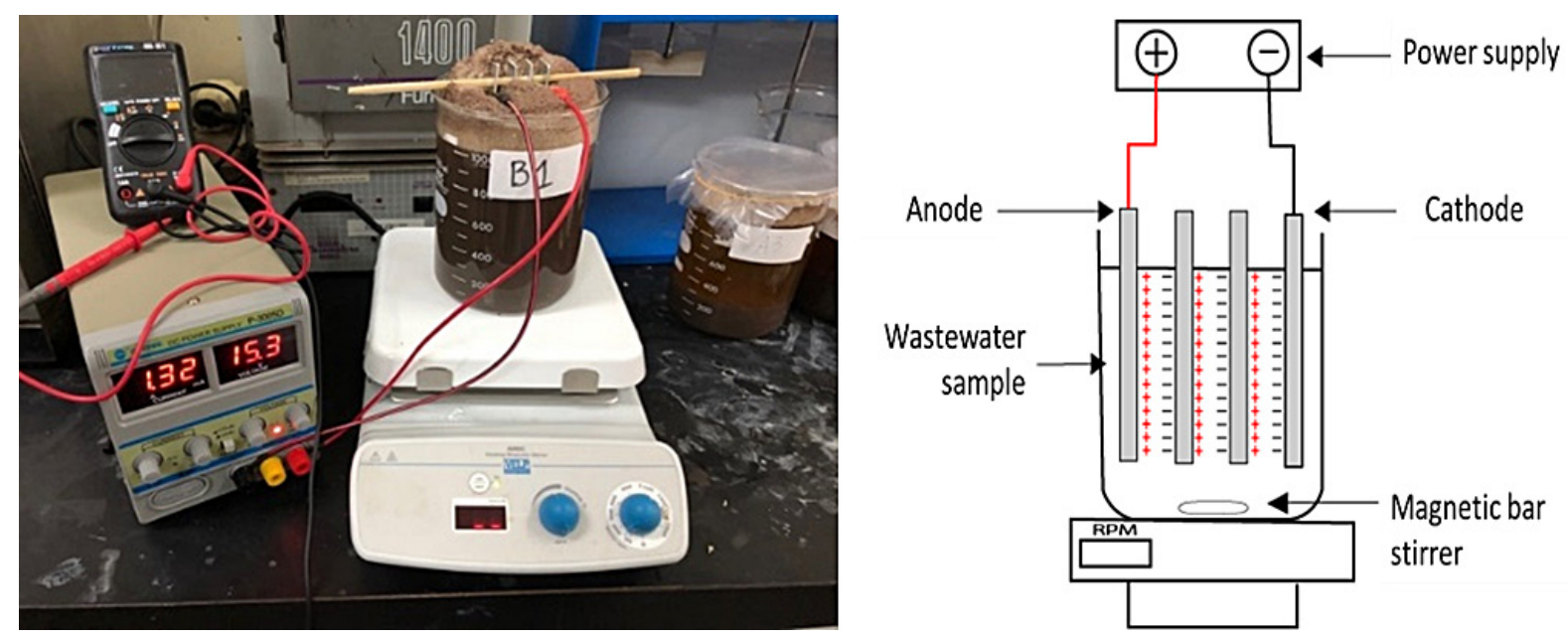

Figure 1. A schematic diagram of the bipolar configuration of the EC reactor 


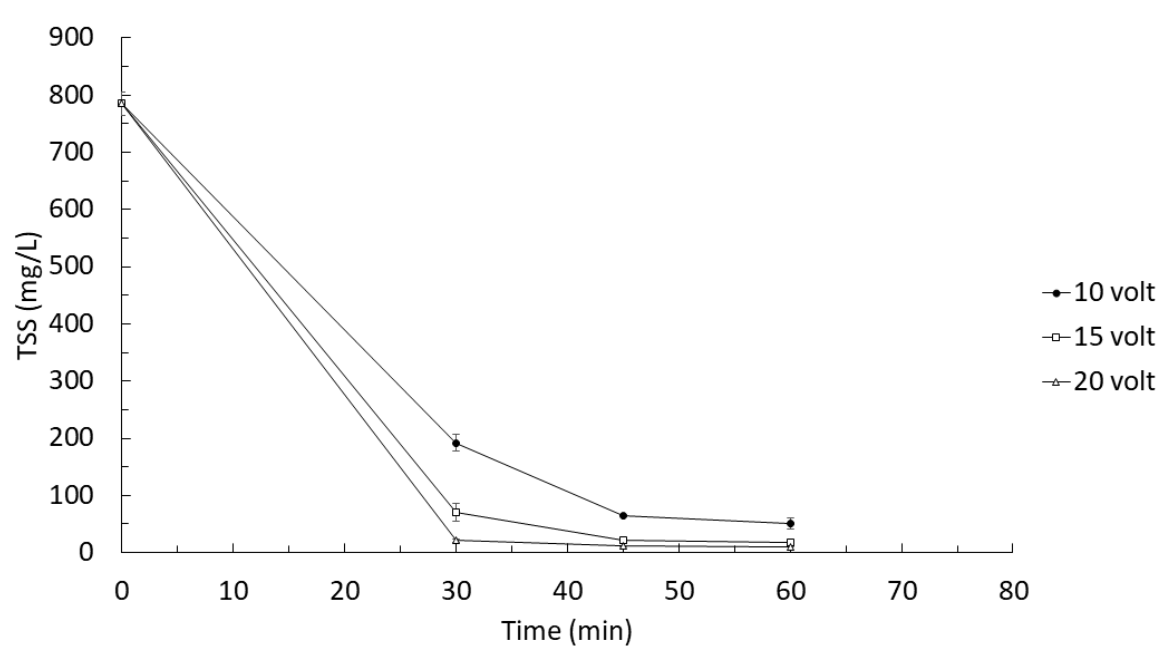

Figure 2. The effect of electric voltage and contact time on the TSS removal

colloids. This explains that the reduction in TSS is proportional to the reduction in turbidity of wastewater. Figure 3 shows the turbidity reduction profile as a function of the applied voltage and contact time. Similar to the TSS removal profile, turbidity decreases very rapidly in the first 30-45 min of EC, afterwards it decreases only slightly. A similar effect also applies to electrical voltage levels; the higher the voltage, the faster the rate of turbidity decreases. At a voltage of $10 \mathrm{~V}$ for $30 \mathrm{~min}$ the rate of turbidity reduction is $54 \%$, while at a voltage of $20 \mathrm{~V}$ for $60 \mathrm{~min}$, the turbidity reduction can reach $98 \%$ which is 4.6 NTU. The same explanation of the TSS removal mechanism also applies to the reduction of turbidity. Cathode electrodialysis produces the $\mathrm{Al}^{3+}$ ions which trigger destabilization of suspensions or colloids, formation of larger, stable, insoluble complexes, and finally settle. On the other hand, the reduction of water at the cathode produces the $\mathrm{H}_{2}$ gas, attaches to and lifts particles or flocs to the surface. As the current increases, higher concentrations of $\mathrm{Al}^{3+}$ occur, resulting in a faster removal of the TSS, turbidity, and other pollutants (Markou et al., 2017).

\section{Color}

The color of wastewater is caused by the presence of dissolved organic and inorganic materials that can be visually observed or measured on a platinum cobalt ( $\mathrm{PtCo}$ ) scale by comparing the sample color and standard color. The color appearance is influenced by the colloidal particles present in wastewater (Malakootian and Fatehizadeh, 2010), so the decrease in the colloidal

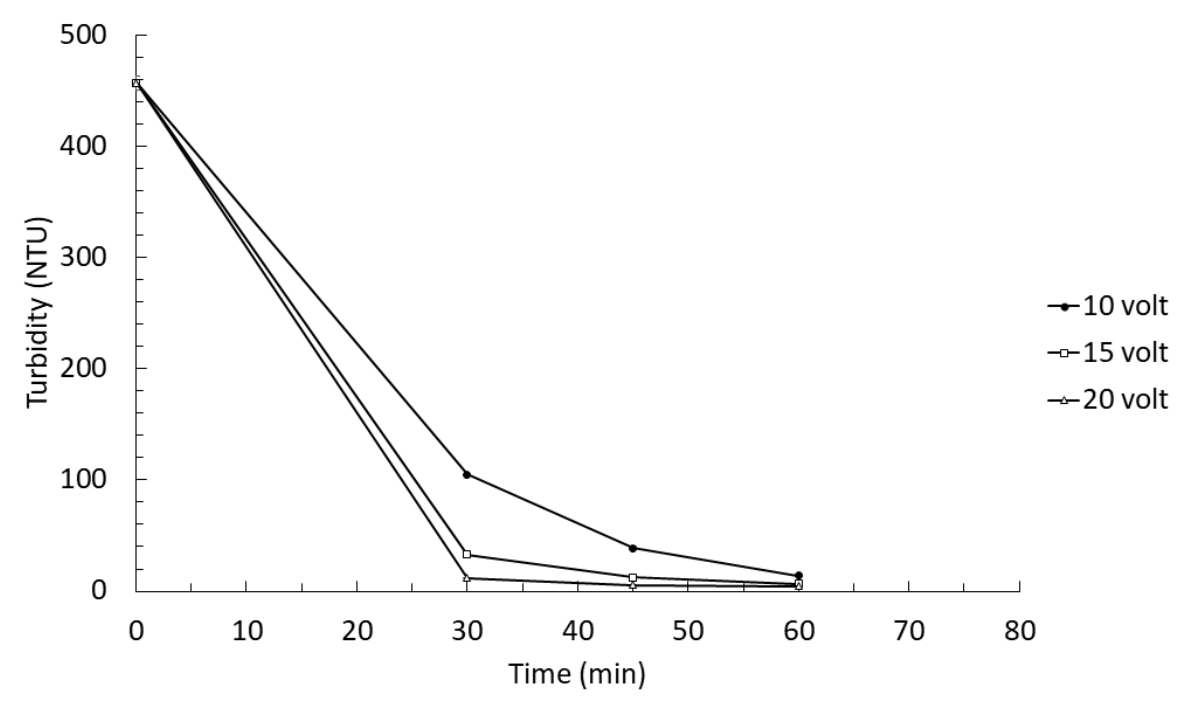

Figure 3. The effect of electric voltage and contact time on turbidity 
particles due to coagulation and flocculation causes a decrease in color. The color sources of wastewater include iron ions, manganese oxide, tannins, lignin, and others (Spellman, 2008). As shown in Figure 4, the EC process reduces the color of wastewater by $70 \%$ at a voltage of $10 \mathrm{~V}$ for $30 \mathrm{~min}$. The highest color reduction of $96 \%$ was obtained at a voltage of $20 \mathrm{~V}$ for $60 \mathrm{~min}$, namely $375 \mathrm{PtCo}$. In general, the higher the voltage and contact time, the greater the color reduction. This is due to the higher voltage and longer contact time, which causes that the colloidal particle charge (which is generally negative) becomes neutralized by the $\mathrm{Al}^{3+}$ ion formed, so that the suspended particles or colloids are bound to one another. The colloidal particles that bond together will form lumps and settle at the bottom of the reactor more quickly (Islam et al., 2011a; Islam et al., 2011b). Color removal can also be caused by binding of the color-causing compounds by metals, adsorption by floc formed, or deposition of metals due to increased $\mathrm{pH}$. The decrease in color intensity due to EC, visually, can also be seen in Figure 4. The removal of dissolved substances results in color reduction. On the other hand, the operating conditions (such as dissolved oxygen and $\mathrm{pH}$ ) can oxidize or reduce the color-causing dissolved materials, and certain metals that cause the color of wastewater (Ibrahim et al., 2018).

\section{COD and $\mathrm{BOD}_{5}$ removals}

The effects of electrical voltage and contact time on the content of organic pollutants, which are quantitatively expressed in $\mathrm{COD}$ and $\mathrm{BOD}_{5}$, are presented in Figs. 5 and 6. The effluent COD and $\mathrm{BOD}_{5}$ decrease with increasing contact time. The reduction in organic pollutants occurs as a result of colloidal destabilization by the $\mathrm{Al}^{3+}$ cations forming polyvalent polyhydroxides. This complex compound has a high adsorption capacity, thus encouraging aggregation with various dissolved pollutants to form larger flocks, which are easier to precipitate. A COD reduction of $80 \%$ is achieved at $10 \mathrm{~V}$ for $30 \mathrm{~min}$ and increased to $91 \%$ at $20 \mathrm{~V}$ with the same contact time, i.e. at COD $520 \mathrm{mg} / \mathrm{L}$. In terms of $\mathrm{BOD}_{5}$, the $\mathrm{EC}$ process at $20 \mathrm{~V}$ for $30 \mathrm{~min}$ can reduce the effluent $\mathrm{BOD}_{5}$ by $99 \%$ or at $32 \mathrm{mg} / \mathrm{L}$. The reduction of $C O D$ and $B O D$ results from the removal of suspended and dissolved organic matter, colloid, and emulsion breakdown, complex formation of organic metals, oxidation by oxygen (Kabdaşlı et al., 2012; Bharath et al., 2018; Brahmi et al., 2019).

\section{$\mathrm{pH}$}

One important parameter of wastewater quality is $\mathrm{pH}$ because of its significant effect on the environment. Figure 7 shows the change in $\mathrm{pH}$ for the operating conditions under study. The $\mathrm{pH}$ value tends to increase along with voltage and contact time, with the highest value being 8.6 at $15 \mathrm{~V}$ for $60 \mathrm{~min}$. increasing the $\mathrm{pH}$ of the solution is an advantage of this method compared to chemical coagulation (CC). The $\mathrm{CC}$ process tends to reduce $\mathrm{pH}$, especially for wastewater with low alkalinity. The increase in $\mathrm{pH}$ in $\mathrm{EC}$ can be explained by the following

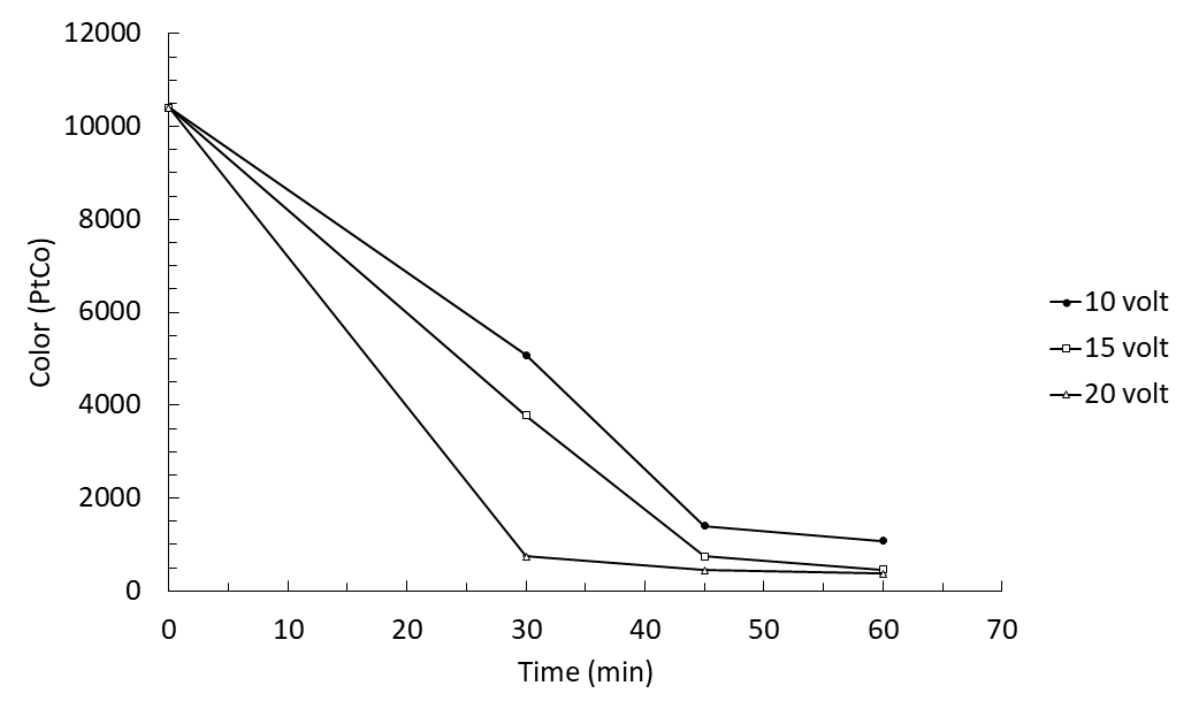

Figure 4. The effect of electric voltage and contact time on color 


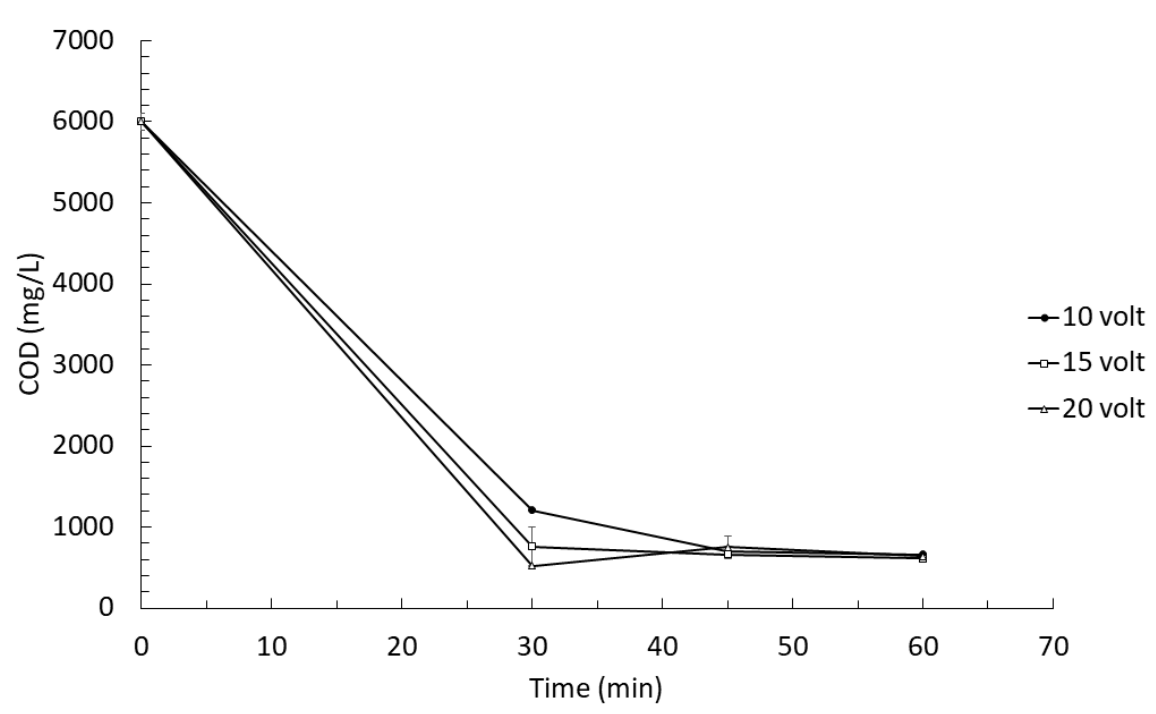

Figure 5. The effect of electric voltage and contact time on effluent COD

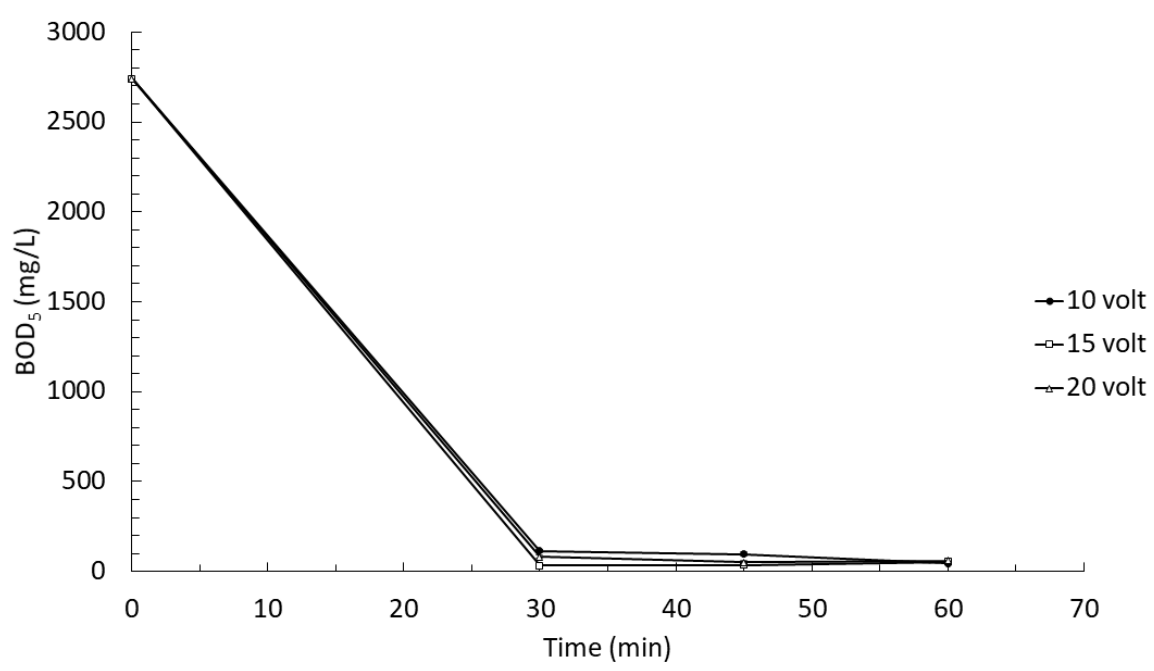

Figure 6. The effect of electric voltage and contact time on effluent $\mathrm{BOD}_{5}$

reaction, where electrolysis of aluminum metal produces the trivalent aluminum ions $\left(\mathrm{Al}^{3+}\right)$ which also simultaneously produce the $\mathrm{OH}$ ions, causing an increase in alkalinity or $\mathrm{pH}$ of wastewater, in Eqs. (2) and (3).

$$
\begin{gathered}
\mathrm{Al}_{(\mathrm{s})} \rightarrow \mathrm{Al}_{(\mathrm{aq})}{ }^{3+}+3 \mathrm{e}^{-} \\
\mathrm{Al}^{3+}{ }_{(\mathrm{aq})}+3 \mathrm{H}_{2} \mathrm{O} \rightarrow \mathrm{Al}(\mathrm{OH})_{3(\mathrm{~s})}+3 \mathrm{H}^{+}{ }_{(\text {aq })}
\end{gathered}
$$

Cathode electrolysis produces the $\mathrm{OH}^{-}$ions, tends to increase $\mathrm{pH}$, and causes a variety of additional positive effects, such as decrease the solubility and precipitation of certain metals (Brahmi et al., 2019).

The EC process uses aluminum electrodes in a combination of electrical voltage and contact time applied in this study, as described above, proven to eliminate suspended (insoluble) solids and dissolved pollutants simultaneously. On the basis of these experimental data, a correlation between the TSS reduction and reduced turbidity, color, $\mathrm{COD}$, and $\mathrm{BOD}_{5}$ can be made and the results are presented in Figure 8.

In the EC process with aluminum as an electrode, the electric current passed through the electrode oxidizes $\mathrm{Al}$ to its cation $\left(\mathrm{Al}^{3+}\right)$ and simultaneously reduces water to the $\mathrm{OH}^{-}$ions and hydrogen gas $\left(\mathrm{H}_{2}\right)$ at the cathode. The reactions are presented in Eqs. (4) and (5).

$$
\begin{aligned}
\mathrm{Al} & \rightarrow \mathrm{Al}^{3+}+3 \mathrm{e}^{-} \\
2 \mathrm{H}_{2} \mathrm{O}_{(\mathrm{l})} & \rightarrow \mathrm{OH}^{-}+\mathrm{H}_{2(\mathrm{~g})}
\end{aligned}
$$

Furthermore, the $\mathrm{Al}^{3+}$ cations react with water to form aluminium hydroxide, in Eq. (6).

$$
\mathrm{Al}^{3+}{ }_{(\text {aq })}+3 \mathrm{H}_{2} \mathrm{O} \rightarrow \mathrm{Al}(\mathrm{OH})_{3(\mathrm{~s})}+3 \mathrm{H}^{+}{ }_{(\mathrm{aq})}
$$




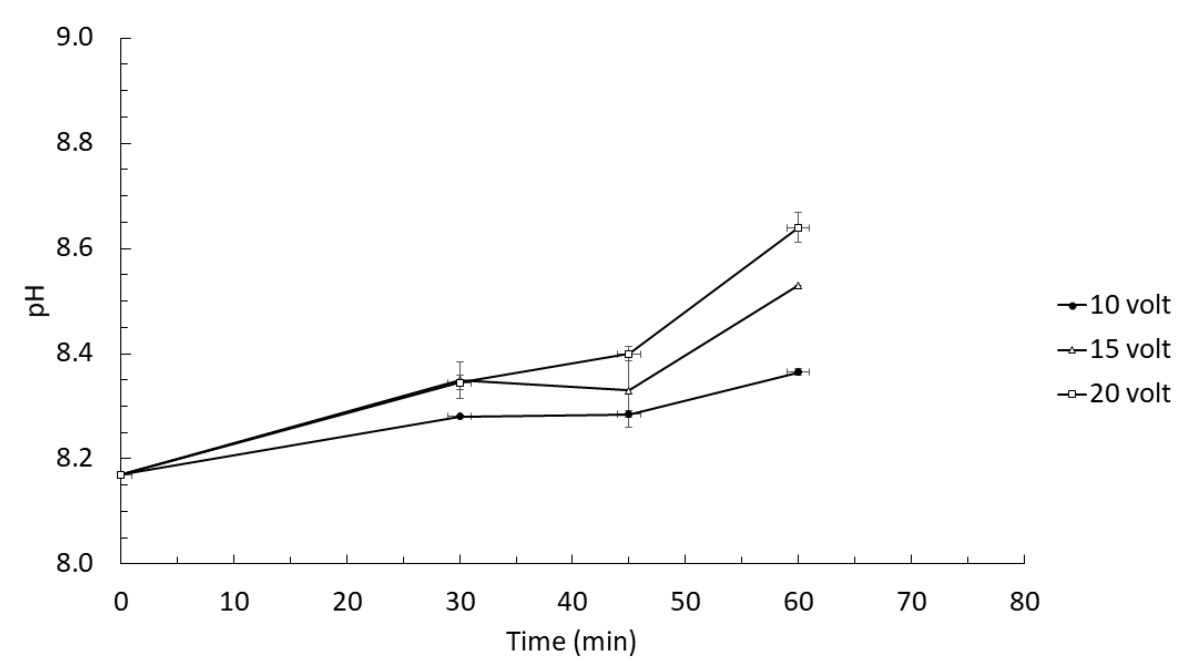

Figure 7. The effect of electric voltage and contact time on effluent $\mathrm{pH}$

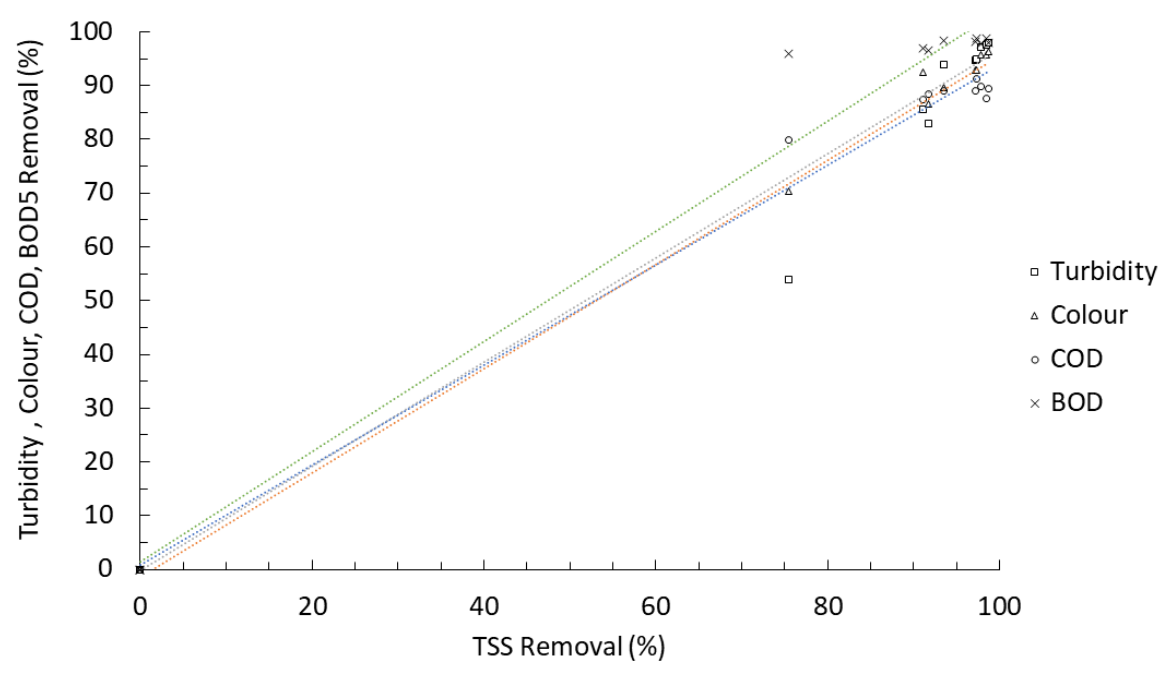

Figure 8. Correlation between the TSS reduction and removal of turbidity, color, $\mathrm{COD}$ and $\mathrm{BOD}_{5}$

Aluminum hydroxide, which has a high adsorption capacity, will bind pollutants to form larger flocks and sweep out particles in water. Depending on the reaction conditions, such as oxygen concentration and $\mathrm{pH}$, oxidation or reduction of pollutants can also occur (decolorization). Because $\mathrm{H}_{2}$ is formed, these gas bubbles can also cause electroflotation and particle adhesion (Kabdaşli et al., 2012). The process of removing pollutants can take place sequentially or synergistically. The dominant process in removing pollutants depends on many factors, such as operating conditions, type of electrodes, and type of wastewater. The mechanisms and processes that might be involved in the removal of pollutants include coagulation, aggregation, flocculation of suspended particles, complexation with metals, precipitation, sedimentation or flotation by the $\mathrm{H}_{2}$ gas.

\section{Characteristics of the EC treated wastewater}

The results of EC treatment in various combinations of the operating conditions studied are visually shown in Figure 9. The EC process has changed the appearance of the anaerobically-pretreated POME which was originally turbid and jet black to clear and brown. These figures also show the formation of large amounts of deposits at the bottom of the reactor. In general, the amount of deposits increases along with voltage and contact time. Table 2 presents the results of quantitative analysis of wastewater characteristics before and after EC treatment. It is clear from all the measured quality parameters that the EC process improves the wastewater quality.

Referring to Regulation of the Minister of Environment of the Republic of Indonesia No. $5 / 2014$, except for COD, all parameters of the 


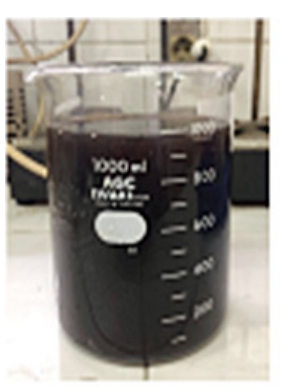

(a)

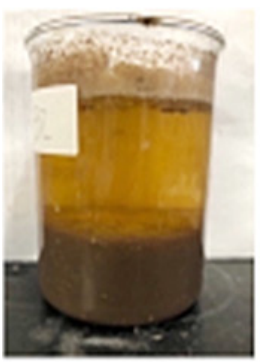

(f)

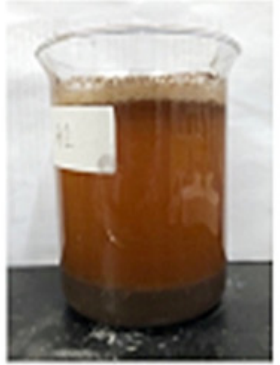

(b)

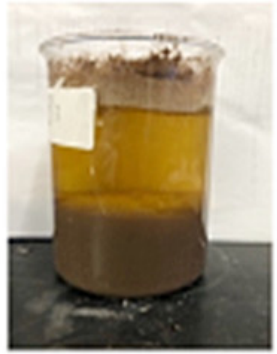

(g)

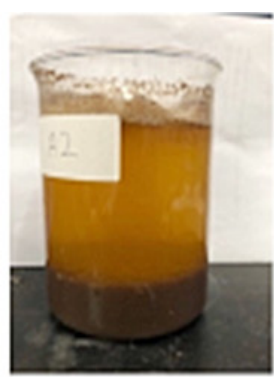

(c)

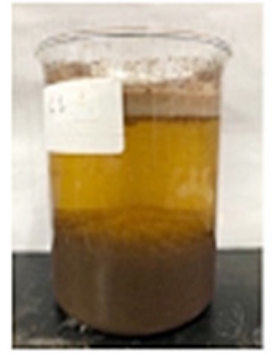

(h)

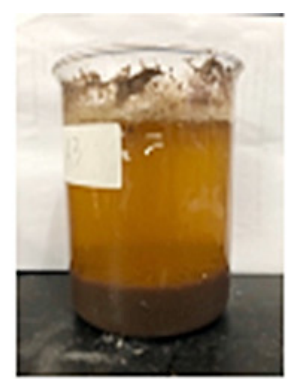

(d)

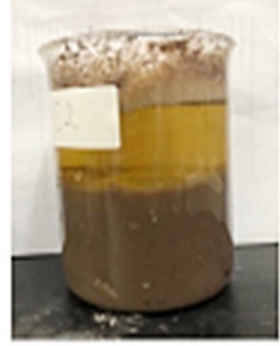

(i)

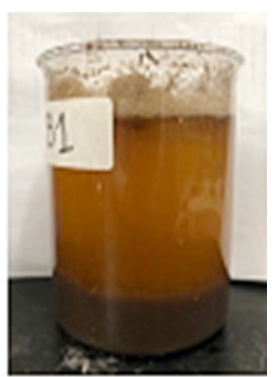

(e)

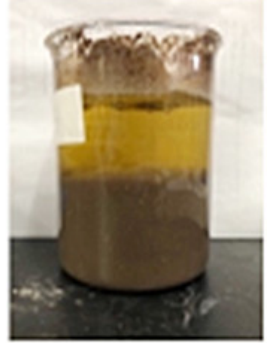

(j)

Figure 9. Visual appearance of the anaerobically-pretreated POME before and after EC treatment: (a) before treatment, (b) $10 \mathrm{~V}$ for $30 \mathrm{~min}$, (c) $10 \mathrm{~V}$ for $45 \mathrm{~min}$, (d) $10 \mathrm{~V}$ for $60 \mathrm{~min}$, (e) $15 \mathrm{~V}$ for $30 \mathrm{~min}$, (f) 15 for $45 \mathrm{~min}$, (g) $15 \mathrm{~V}$ for $60 \mathrm{~min}$, (h) $20 \mathrm{~V}$ for $30 \mathrm{~min}$, (i)

wastewater quality have been met through the EC treatment. On the basis of the very small $\mathrm{BOD}_{5} /$ COD ratio $(\approx 0,1)$, it is known that the remaining dissolved organic material is difficult to degrade biologically and cannot be removed by the EC process. In order to produce the effluents that meet the standards, further research is currently being conducted using an adsorption method with empty fruit bunches biochar, which is believed to be effective in removing the pollutant residues.

\section{EC kinetic model}

First and second order kinetics models developed by Singh and Mishra (2016) and Nwabanne et al. (2018) are used to describe the process of removing pollutants, specifically suspended solids. In a batch EC system, the level of pollutant elimination can be stated as Eq. (7).

$$
-\frac{\mathrm{dC}}{\mathrm{dt}}=-\mathrm{r}_{\mathrm{D}}
$$

where: $R_{D}$ is removal rate $(\mathrm{mg} / \mathrm{L} \cdot \mathrm{min})$ and $\mathrm{t}$ is time (min). With the first order model $\left(r_{D}=k_{1} C\right)$, the integration of equation (7) with the initial concentration $\left(C_{0}\right)$ results in Eq. (8).

$$
\mathrm{C}_{\mathrm{t}}=\mathrm{C}_{0} \mathrm{e}^{\mathrm{k}_{1} \mathrm{t}}
$$

where: $k_{1}$ is the first order-rate constant in $\min ^{-1}$. The $k_{1}$ is obtained from the plot of Ln C against time $t$, where the value of $k_{1}$ is the slope (Figure 10). By plotting the experimental data, the values of $k_{1}$ are determined as presented in Table 3 .

Table 2. Characteristics of the anaerobically-pretreated POME before and after EC treatment

\begin{tabular}{|c|c|c|c|c|}
\hline Parameter & Unit & Before Treatment & $\begin{array}{c}\text { After Treatment } \\
\text { (at 15 V for 30 min) }\end{array}$ & $\begin{array}{c}\text { Indonesian Standard } \\
\text { of Effluent Quality }\end{array}$ \\
\hline pH & - & 8.2 & 8.4 & 9.0 \\
\hline TSS & $\mathrm{mg} / \mathrm{L}$ & $785 \pm 20$ & 70 & 250 \\
\hline Turbidity & NTU & $457 \pm 6$ & 33 & - \\
\hline Colour & PtCo & $10,400 \pm 70$ & 775 & - \\
\hline COD & $\mathrm{mg} / \mathrm{L}$ & $6,000 \pm 100$ & 760 & 350 \\
\hline $\mathrm{BOD}_{5}$ & $\mathrm{mg} / \mathrm{L}$ & 2740 & 80 & 100 \\
\hline
\end{tabular}

\footnotetext{
* Minister of Environment Regulation No. 5/2014.
} 


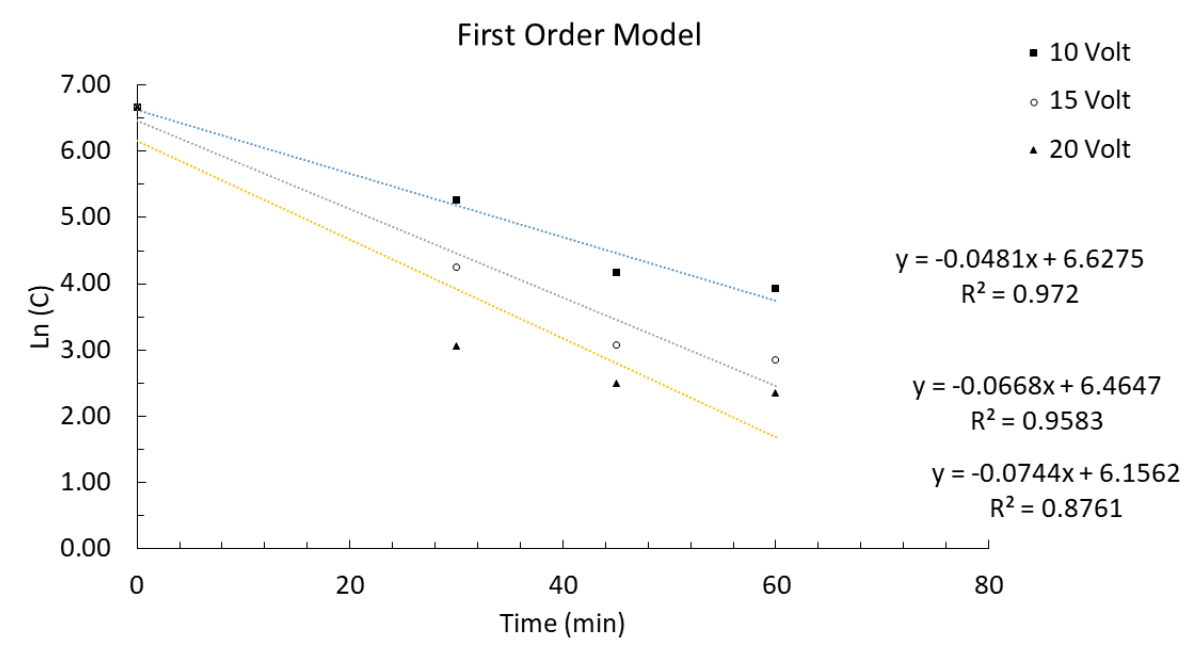

Figure 10. Plot of Ln $\mathrm{C}$ against time $\mathrm{t}$ to obtain $\mathrm{k}_{1}$

For the second order kinetic model $\left(-r_{D}=k_{2} C^{2}\right)$, the concentration dependence on time can be expressed as Eq. (9).

$$
\frac{1}{C_{t}}=\frac{1}{C_{0}}+k_{2} t
$$

where: $k_{2}$ is the second order rate constant in $(\mathrm{mg} / \mathrm{L})^{-1} \mathrm{~min}^{-1}$.

A plot of $-1 / \mathrm{C}$ against time ( $\mathrm{t}$ ) is used to obtain kinetics parameters of $k_{2}$, where $\mathrm{k}_{2}$ can be obtained from the slope of the linear line (Figure 11), as presented in Table 3.

The level of fitting of the kinetic model to the experimental data is determined by using the linear regression coefficient $\left(\mathrm{R}^{2}\right)$. From Table 4 it can be seen that the $\mathrm{R}^{2}$ values for the second order model are in general better than $\mathrm{R}^{2}$ of the first order model. The $\mathrm{R}^{2}$ values are more than 0.9 for all levels of the studied voltage. On the basis of these results, it is recommended that a second order kinetics model be used to describe the TSS removal from the anaerobically-pretreated palm POME for the applied voltages of 10, 15 and $20 \mathrm{~V}$. The models can be written as Eqs. (10), (11), and (12). $\frac{1}{C_{t}}=\frac{1}{C_{0}}+0.0003 . t \quad$ for $10 \mathrm{~V}$

$\frac{1}{C_{t}}=\frac{1}{C_{0}}+0.0010 . t \quad$ for $15 \mathrm{~V}$

$\frac{1}{C_{t}}=\frac{1}{C_{0}}+0.0016 . t \quad$ for $20 \mathrm{~V}$

Figure 12 shows the graphical presentation of second-order kinetics models of TSS removal. The model shows a quantitative relationship between $\mathrm{C}_{\mathrm{o}}, \mathrm{C}_{\mathrm{t}}$, and $\mathrm{t}$ for voltages of 10,15 , and

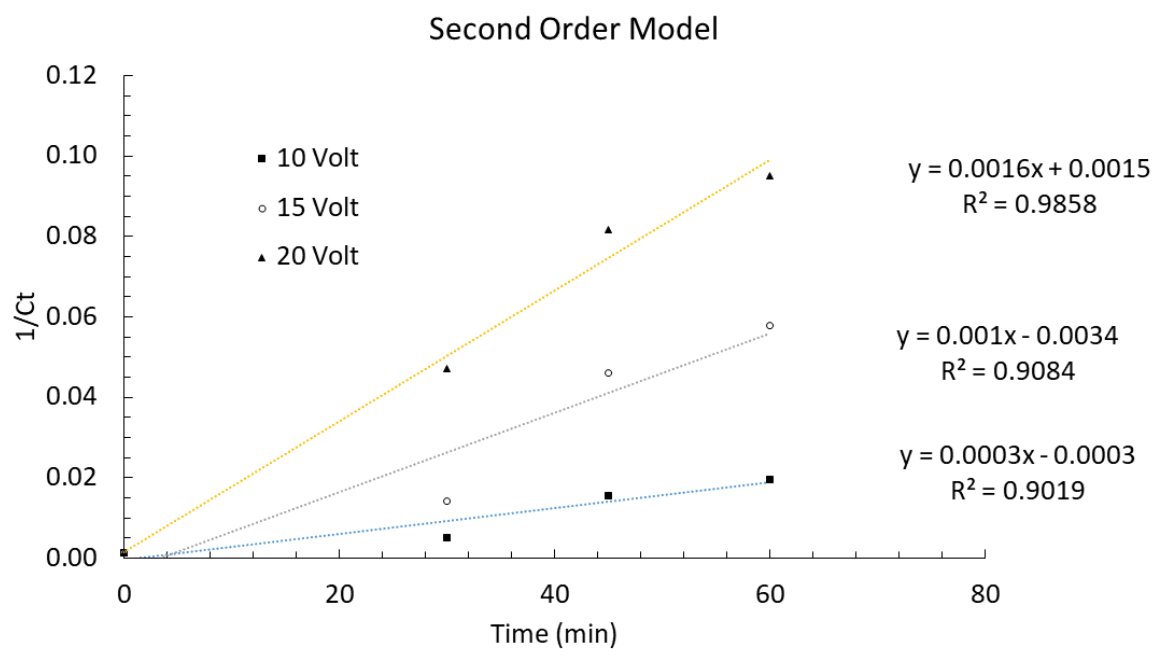

Figure 11. Plot of $-1 / \mathrm{C}$ against time $(\mathrm{t})$ to obtain the kinetics parameter $\mathrm{k}_{2}$ 
Table 3. Values of kinetic parameters of first and second order models with their regression correlation coefficient $\left(\mathrm{R}^{2}\right)$ for 10,15 , and $20 \mathrm{~V}$

\begin{tabular}{|c|c|c|c|}
\hline \multicolumn{4}{|c|}{ First order kinetic model } \\
\hline & $10 \mathrm{~V}$ & $15 \mathrm{~V}$ & $20 \mathrm{~V}$ \\
\hline$k_{1}\left(\mathrm{~min}^{-1}\right)$ & 0.0481 & 0.0668 & 0.0744 \\
\hline $\mathrm{R}^{2}$ & 0.9720 & 0.9583 & 0.8761 \\
\hline \multicolumn{4}{|c|}{ Second order kinetic model } \\
\hline$k_{2}(1 /(\mathrm{mg} / \mathrm{L}) \mathrm{min})$ & $10 \mathrm{~V}$ & $15 \mathrm{~V}$ & $20 \mathrm{~V}$ \\
\hline $\mathrm{R}^{2}$ & 0.0003 & 0.0010 & 0.0016 \\
\hline
\end{tabular}

$20 \mathrm{~V}$. With the help of this model, the TSS removal efficiency and $\mathrm{C}_{\mathrm{t}}$ can be estimated at various t. In other words, to achieve the value of $\mathrm{C}_{t}$ or certain efficiency, it can be estimated the contact time needed for $\mathrm{EC}$, if $\mathrm{C}_{\mathrm{o}}$ is known. With the known $t$ required, the reactor volume (v) can be estimated, if the flow (Q) of effluent is known as Eq. (13).

$$
\mathrm{v}=\mathrm{Q} . \mathrm{t}
$$

\section{Energy consumption and operating cost}

In contrast to chemical coagulation, where the process for removing pollutants requires chemicals such as aluminum sulfate $\mathrm{Al}_{2}\left(\mathrm{SO}_{4}\right)_{3}$ or poly aluminum chloride (PAC), the EC process does not use coagulant chemicals. However, this process requires electrical energy and electrode replacement in its operations, which are the major operating cost components in the EC process. Electrical energy consumption for electrocoagulation can be estimated with the help of Eq. (14) (Geraldino et al., 2015; Brahmi et al., 2019).

$$
\mathrm{W}=\frac{\mathrm{V} \times \mathrm{i} \times \mathrm{t}}{\mathrm{V}}
$$

where: $W$ is electrical energy consumption $\left(\mathrm{kWh} / \mathrm{m}^{3}\right)$,

$V$ is voltage (Volt),

$i$ is electrical current (Ampere),

$t$ is contact time $(\mathrm{h})$, and

$v$ is wastewater volume $\left(\mathrm{m}^{3}\right)$.

Electrode consumption is estimated using Eq. (15).

$$
\mathrm{C}=\frac{\mathrm{i} \times \mathrm{t} \times \mathrm{M}}{\mathrm{F} \times \mathrm{ZxV}}
$$

where: $C$ is electrode consumption $\left(\mathrm{g} / \mathrm{m}^{3}\right)$,

$i$ is electrical current (A),

$t$ is contact time (s),

$M$ is molecular mass $(\mathrm{g} / \mathrm{mol})$,

$F$ is a Faraday constant $(96,485 \mathrm{C} / \mathrm{mol})$,

$z$ is number of electron, and

$V$ wastewater volume $\left(\mathrm{m}^{3}\right)$.

Thus, the operational costs of the EC process are the sum of the two costs (Eq. 16).

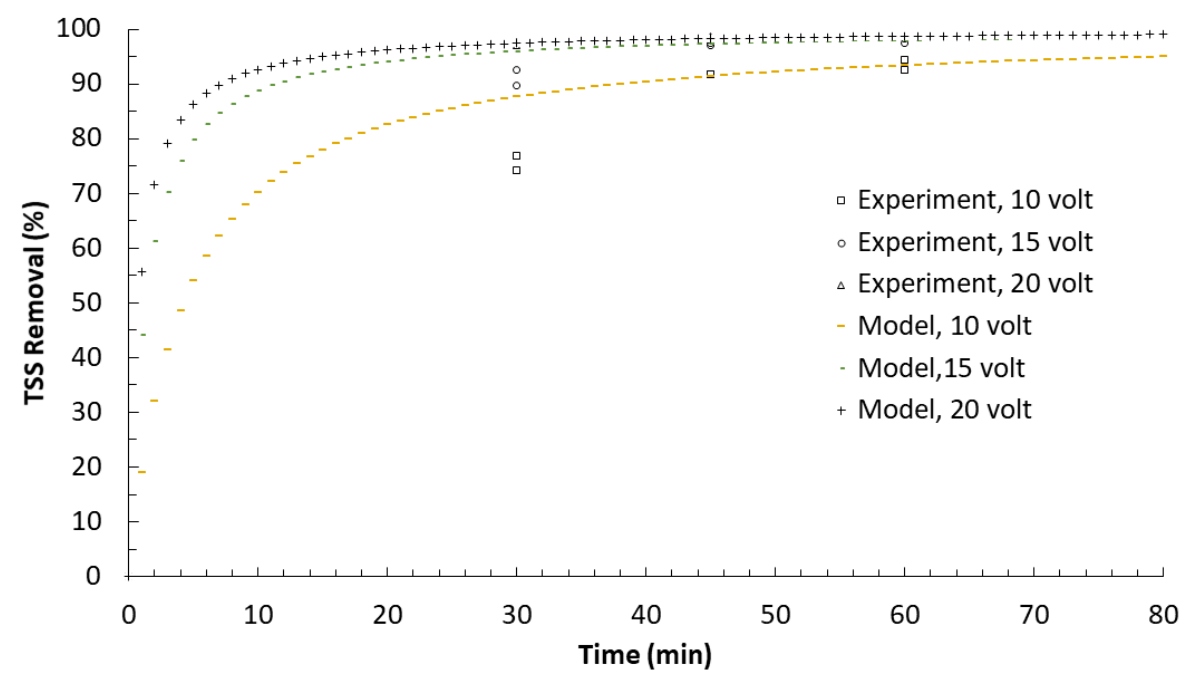

Figure 12. Graphical presentation of second-order kinetics model of the TSS removal 


$$
\mathrm{B}_{\mathrm{o}}=(\mathrm{a} . \mathrm{W})+(\mathrm{b} . \mathrm{C})
$$

where: $B_{o}$ is the operational cost $\left(\mathrm{USD} / \mathrm{m}^{3}\right)$, $a$ is the price of electricity (USD/kWh), $W$ is the electricity consumption $\left(\mathrm{kWh} / \mathrm{m}^{3}\right)$,

$b$ is the price of aluminum (USD $/ \mathrm{kg}$ ), and $C$ is the electrode consumption $\left(\mathrm{kg} / \mathrm{m}^{3}\right)$.

Table 4 shows the estimated electrical energy requirements, electrode consumption and operating costs calculated using Eqs. 14, 15 and 16 above. For example, to remove $87 \%$ COD, $97 \%$ BOD $_{5}, 90 \%$ TSS, $93 \%$ color, and $86 \%$ turbidity with EC operated at $15 \mathrm{~V}$ for $30 \mathrm{~min}$ requires electrical energy of $10.58 \mathrm{kWh} / \mathrm{m}^{3}$ (0.71 USD) and electrode replacement of $0.2367 \mathrm{~kg} / \mathrm{m}^{3}(0.76$ USD). Thus the total operating costs for the EC process conditions studied range from 1.48 USD

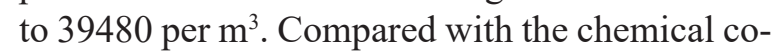
agulation method, the EC process requires lower costs and shows better efficiency in removing various pollutants. In comparison, Hassan and Puteh (2007) reported that the POME treatment using chemical coagulation method consumed $8 \mathrm{~g} / \mathrm{L}$ alum $\left(5.42 \mathrm{USD} / \mathrm{m}^{3}\right)$ with a turbidity removal rate of $99 \%$, COD $49 \%$, and TSS $99 \%$. As shown in Table 4, the electrode costs account for around $50 \%$ of the total operating costs. This cost can be reduced or even eliminated, if aluminum scrap is used as an electrode. Recycling and reuse can reduce the processing costs and also reduce the aluminum waste. Furthermore, because POME generally does not contain heavy metals or harmful synthetic organic materials in high concentrations, the precipitate formed from the EC process can be used as an organic fertilizer for agriculture. It should be emphasized here that the operating costs are highly dependent on the EC operating conditions, especially the voltage and contact time. The cost calculation presented in Table 4 is only a rough estimate using a number of assumptions. In order to obtain an accurate calculation, a more specific study need to be conducted by considering the actual local conditions.

\section{CONCLUSION}

Electrocoagulation has been developed as an alternative of POME treatment which is more environmentally-friendly and easy to operate. This study shows that electrocoagulation with aluminum electrodes can significantly reduce various types of pollutants of anaerobically-pretreated POME, such as TSS, turbidity, color, COD, and $\mathrm{BOD}_{5}$. Electric voltage and contact time have been determined to evaluate the electrocoagulation performance in term of pollutants removal. The elimination rate of pollutants increases along with the electric voltage and contact time. The higher the voltage, the greater the electric current produced and the more $\mathrm{Al}^{3+}$ ions were formed. As a result, more flocks were formed and more suspended solids could be removed. The longer contact time, causing more suspended particles bound to one another and settle at the bottom of the reactor more quickly. The rate of pollutant reduction significantly occurs during the first $30 \mathrm{~min}$, after which the rate of decline is no longer significant. The EC process at a voltage of $20 \mathrm{~V}$ and a contact time of 30 min can reduce TSS, turbidity, color, COD, and $\mathrm{BOD}_{5}$ by $90 \%, 86 \%, 93 \%, 87 \%$, and $97 \%$, respectively. The removal of TSS from anaerobically-pretreated POME can be explained by a second-order kinetics model. From experimental data, the kinetic constant is calculated to have a value between 0.0003 to $0.0016 \mathrm{mg} / \mathrm{L} / \mathrm{min}$ for a voltage range of $10-20 \mathrm{~V}$, so that the relationship between the effluent TSS concentration, influent TSS concentration, and contact time can be determined quantitatively. This kinetic model can be used to evaluate the level of TSS removal in EC

Table 4. Estimation of EC operating costs

\begin{tabular}{|l|c|c|}
\hline \multicolumn{1}{|c|}{ Component } & Operating Condition 1 & Operating Condition 2 \\
\hline Voltage $(\mathrm{V})$ & 20 & 30 \\
\hline Contact time $(\mathrm{min})$ & 30 & 1.4 \\
\hline Electrical current $(\mathrm{A})$ & 2.2 & 10.6 \\
\hline Energy consumption $\left(\mathrm{kWh} / \mathrm{m}^{3}\right)$ & 22 & 0.71 \\
\hline Cost of energy $\left(\mathrm{USD} / \mathrm{m}^{3}\right)$ & 1.49 & 0.24 \\
\hline Electrode Consumption $\left(\mathrm{kg} / \mathrm{m}^{3}\right)$ & 0.37 & 0.76 \\
\hline Cost for electrode $\left(\mathrm{USD} / \mathrm{m}^{3}\right)$ & 1.19 & 1.48 \\
\hline Operating cost $\left(\mathrm{USD} / \mathrm{m}^{3}\right)$ & 2.67 & \\
\hline
\end{tabular}

* Electrode price: $3.22 \mathrm{USD} / \mathrm{kg}$ 
systems and to determine the volume of reactors needed to treat wastewater with known flow rates and TSS levels. The cost analysis shows that the operating costs of the EC process are estimated to range $1.48 \mathrm{USD}$,- to $2.67 \mathrm{USD}$ per $\mathrm{m}^{3}$ to achieve the desired level of pollutant removal. This cost is cheaper than that of chemical coagulation. The results of this study can be used as a basis for optimizing and scaling up on a continuous EC system. The development of more advanced effluent treatment methods is still needed, especially for the recycling purposes. Further research on the EC processes should consider other factors, including current density, temperature, and electrode materials.

\section{Acknowledgement}

The authors are very grateful to the Laboratory of Environmental Engineering Management, IPB University, for financial support and facilitation of this experimental work.

\section{REFERENCES}

1. Al-Qodah Z., Tawalbeh M., Al-Shannag M., AlAnber Z., Bani-Melhem K. 2020. Combined electrocoagulation processes as a novel approach for enhanced pollutants removal: A state-of-the-art review. Sci. Total. Environ., 744, 1-67.

2. APHA. 2017. Standar method for the examination of water and wastewater. American Public Health Association. 23rd Ed. APHA, Washington, DC.

3. Bharath M., Krishna B.M., Manoj K.B. 2018. A review of electrocoagulation process for wastewater treatment. Int. J. Chem. Technol. Res., 11(3), 289-302.

4. BPS (Indonesia Central Bureau of Statistics). 2019. Foreign trade statistics bulletin. BPS RI.

5. Brahmi K., Bouguerra W., Hamrouni B., Elaloui E., Loungou M., Tlili Z. 2019. Investigation of electrocoagulation reactor design parameters effect on the removal of cadmium from synthetic and phosphate industrial wastewater. Arab J. Chem., 12, 1848-1859.

6. Butler E., Hung Y-T., Yeh RY-L., Suleiman A.A.M. 2011. Electrocoagulation in wastewater treatment. Water, 3, 495-525.

7. de la Luz-Pedro A., Prior E.F.M., Lopez-Araiza M.H., Jaime-Ferrer S., Estrada-Monje A., Banuelos J.A. 2019. Pollutant removal from wastewater at different stages of the tanning process by electrocoagulation. J. Chem., 2019, 1-9.
8. de Souza M.T.F., Ambrosio E,; de Almeida C.A., Freitas T.K.F.S., Santos L.B., Almeida V.C., Garcia J.C. 2014. The use of a natural coagulant (Opuntia ficus-indica) in the removal for organic materials of textile effluents. Environ. Monit. Assess., 186, 5261-5271.

9. Essadki A.H., Gourich B., Azzi M., Vial C.H., Delmas H. 201). Kinetic study of defluoridation of drinking water by electrocoagulation/electroflotation in a stirred tank reactor and in an external-loop airlift reactor. Chem. Eng. J., 164, 106-114.

10. Geraldino H.C.L., Simionato J.I., Freitas T.K.F.S., Garcia J.C., Junior O.C., Correr C.J. 2015. Efficiency and operating cost of electrocoagulation system applied to the treatment of dairy industry wastewater. Acta Sci. Technol., 37, 401-408.

11. Hasanudin U., Sugiharto R., Haryanto A., Setiadi T., Fujie K. 2015. Palm oil mill effluent treatment and utilization to ensure the sustainability of palm oil industries. Water Sci. Technol., 72(7), 1089-1095.

12. Hassan M.A.A., Puteh M.H. 2007. Pre-treatment of palm oil mill effluent (POME): a comparison study using chitosan and alum. Malays. J. Civ. Eng., 19(2), $38-51$.

13. Hossain M.S., Omar F., Asis A.J., Bachmann R.T., Sarker M.Z.I., Kadir M.O.A. 2019. Effective treatment of palm oil mill effluent using $\mathrm{FeSO} 4.7 \mathrm{H} 2 \mathrm{O}$ waste from titanium oxide industry: Coagulation adsorption isotherm and kinetics studies. J. Clean. Prod., 219, 86-98.

14. Ibrahim S., Aris N.S.M., Ariffin B., Hawari Y., Kamal M.A., Hanafiah M. 2018. Application of electrocoagulation process for decolourisation of palm oil mill effluent (POME). Nat. Environ. Pollut. Technol., 17(4), 1267-1271.

15. Islam S.M.N., Rahman S.H., Rahman M.M., Adyel T.M., Yesmin R.A., Ahmed M.S., Kaiser N. 2011. Excessive turbidity removal from textile effluents using electrocoagulation technique. J. Sci. Res., 3(3), 557-568.

16. Islam S.M.N., Rahman S.H., Adyel M.T., Ahmed M.S., Yesmin R.A., Rahman M.M., Kaiser N. 2011. Electrocoagulation (EC) technique for color removal from orange II dye. Bangladesh J. Environ. Res., 9, 45-52.

17. Islam S.M.D. 2017. Electrocoagulation (EC) technology for wastewater treatment and pollutants removal. Sustain. Water Resour. Manage., 5, 359-380.

18. Kabdaşlı I., Arslan-Alaton I., Ölmez-Hancı T., Tünay O. 2012. Electrocoagulation applications for industrial wastewaters: a critical review. Environ. Technol. Rev., 1(1), 2-45.

19. Liew R.K., Nam W.L., Chong M.Y., Phang X.Y., Su M.H., Yek P.N.Y., Ma N.L., Cheng C.K., Chong C.T., Lam S.S. 2018. Oil palm waste: An abundant and promising feedstock for microwave pyrolysis 
conversion into good quality biochar with potential multi-applications. Process Saf. Environ. Prot., 115, 57-69.

20. Malakootian M., Fatehizadeh A. 2010. Color removal from water by coagulation/caustic soda and lime. Iran J. Environ. Heal. Sci. Eng., 7(3), 267-272.

21. Markou V., Kontogianni M.C., Frontistis Z., Tekerlekopoulou A.G., Katsaounis A., Vayenas D. 2017 .Electrochemical treatment of biologically pretreated dairy wastewater using dimensionally stable anodes. J. Environ. Manage., 202, 217-224.

22. Marriaga-Cabrales N., Machuca-Martínez F. 2014. Fundamentals of electrocoagulation, in: PeraltaHernández J.M., Rodrigo-Rodrigo M.A., MartinezHuitle C.A. (Eds.), Evaluation of electrochemical reactors as a new way to environmental protection. Research Signpost, Kerala, India.

23. Mollah M.Y.A., Gomes J.A.G., Das K.K., Cocke D.L. 2010. Electrochemical treatment of orange II dye solution-use of aluminum sacrificial electrodes and floc characterization. J. Hazard Mater., 174, 851-858.

24. Noersatyo, Suprihatin, Iskandar A. 2020. Design of small-scale electrocoagulation reactor for non-sugar removal of sugarcane juice. IOP Conf. Ser. Earth Environ. Sci., 472, 1-11.

25. Nwabanne J.T., Oguegbu O.O., Agu C.M. 2018. Kinetics and performance of coagulation process using Mucuna seed shell for the treatment of paint wastewater. J. Chinese Adv. Mater. Soc., 6, 738-754.
26. Rachmawati B., Yayok S.P., Mirwan M. 2014. Proses elektrokoagulasi pengolahan limbah laundry. J. Ilm. Tek. Ling., 6(1), 15-22.

27. Rahardjo P.N. 2016. Studi banding teknologi pengolahan limbah cair pabrik kelapa sawit. J. Tek. Ling., 10(1), 9-18.

28. Sidik D.A.B., Hairom N.H.H., Mohammad A.W. 2019. Performance and fouling assessment of different membrane types in a hybrid photocatalytic membrane reactor (PMR) for palm oil mill secondary effluent (POMSE) treatment. Process Saf. Environ. Prot., 130, 265-274.

29. Singh H., Mishra B.K. 2016. Performance evaluation of the electro-coagulation treatment process for the removal of total suspended solids and metals from water. Environ. Eng. Res., 1-25.

30. Spellman F.R. 2008. The Science of water: concept and application.CRC Press, Taylor \& Francis Group, USA.

31. Suprihatin, Aselfa F.S. 2020. Pollutants removal in electrocoagulation of detergent wastewater. IOP Conf. Ser. Earth Environ. Sci., 472, 1-11.

32. Verma M., Kumar R.N. 2018. Coagulation and electrocoagulation for co-treatment of stabilized landfill leachate and municipal wastewater. J. Water Reuse Desalin., 8, 234-243.

33. Wang J., Mahmood Q., Qiu J.P., Li Y.S., Chang Y.S., Li X.D. 2015. Zero discharge performance of an industrial pilot-scale plant treating palm oil mill effluent. Biomed Res. Int., 2015, 1-9. 